\title{
On Not Living with a Partner: Unpicking Coupledom and Cohabitation
}

\author{
by Sasha Roseneil \\ University of Leeds
}

Sociological Research Online, Volume 11, Issue 3,
<http://www.socresonline.org.uk/11/3/roseneil.html>.

Received: 3 Apr 2006 Accepted: 30 Jul 2006 Published: 30 Sep 2006

\begin{abstract}
The contemporary normative model of sexual/ love relationships assumes a teleology in which some time after getting together two people instantiate their state of coupledom by moving in together. As a consequence, those who do not cohabit with a partner are generally thought not to be coupled. Social researchers have largely shared this understanding of intimate relationships, operating with a tripartite model of relationships in which people are single, cohabiting or married. This paper seeks to unpick the assumed contiguity of coupledom and cohabitation, and to deconstruct the category of 'single'. It draws on data from an intensive investigation of the relationship experiences, practices and values of people who are not living with a partner. It starts with a discussion of the prevalence of not living with a partner, offering a commentary on recent demographic data and quantitative research. It then sets out the methodology used in research, and describes the sample, before exploring the diverse practices of partnership and orientations towards (non) cohabitation of those interviewees who were in non-residential couple relationships. Three main orientations are identified amongst the partnered (living apart together, or LAT) interviewees: living apart regretfully; living apart gladly and living apart undecidedly. The individual and relational contexts of these orientations are then discussed.
\end{abstract}

\section{Keywords: Sexual Love Relationship; Partnership; Couple, Coupledom; Intimacy; Cohabitation; Living Apart Together (LAT); Single; Household}

\section{Introduction}

1.1 Whilst there has been an explosion of sociological research exploring the proposition that there has been a "transformation of intimacy" (Giddens, 1992) in western societies, sociologists have paid little explicit attention to those who are living outside conventional coupledom. One of the most significant, yet largely unremarked upon, changes in personal life of recent years has been the rise in the number of people who do not live with a partner. With the decline in the popularity of marriage and the rise in heterosexual cohabitation, being recognized as a couple no longer requires marriage, but instead coupledom has come to be marked by cohabitation. Since cohabitation has become almost completely normalized (Ermisch and Francesconi, 2000) and morally acceptable (Lewis, 2001; Jamieson et al, 2002; Duncan, Barlow and James, 2005), both as an alternative and sequential to marriage (Lewis, 2001), the dominant normative model of relationships now assumes a teleology in which some time after getting together two people instantiate their state of coupledom by moving in together. As a consequence, those who do not cohabit with a partner are generally thought not to be coupled. Social researchers have largely shared this understanding of intimate relationships, operating with a tripartite model of relationships in which people are single, cohabiting or married.

1.2 This paper seeks to unpick the assumed contiguity of coupledom and cohabitation, and in so doing, it deconstructs the category of "single". It draws on data from an intensive investigation (Sayer, 1992) of the relationship experiences, practices and values of people who are not living with a partner. Previous research has approached this population in terms of distinct groupings - single people, people living alone, lone parents, those living in shared households, and, most recently, couples "living apart together". In contrast, the research reported here encompasses people in all of these groupings. The paper starts with a 
discussion of the prevalence of not living with a partner, offering a commentary on recent demographic data and quantitative research. It then sets out the methodology used in the research, and describes the sample, before exploring the diverse practices of partnership and orientations towards (non) cohabitation of those interviewees who were in non-residential couple relationships. The individual and relational contexts of these orientations are then discussed.

\section{The Prevalence of Not Living with a Partner}

2.1 Alongside the decline in the popularity of marriage and the increase in heterosexual cohabitation since the 1970s (Ermisch and Francesconi, 2000), not living with a partner has also become more common. In the UK in $197919 \%$ of people ${ }^{[1]}$ did not live with a partner, rising to $29 \%$ by 2004 (Table 1), and in 1979 $34 \%$ of households did not contain a (heterosexual) couple, rising to $44 \%$ of households by 2004 (Table 2 ) (GHS, 2004) ${ }^{[2]}$ In order to unpack this rise in the proportion of people living without a co-resident partner, we need to look at statistics on a number of dimensions of change: solo living, singleness and nonresidential partnerships.

Table 1. Percentage of people ${ }^{[3]}$ living in different types of household: 1979 and 2004

\begin{tabular}{|l|l|l|}
\hline & 1979 & 2004 \\
\hline Living in Household Type & $\%$ & $\%$ \\
\hline Married or cohabiting couple & 78 & 70 \\
\hline 2 or more families & 2 & 2 \\
\hline Total living in couple households & 80 & 72 \\
\hline 1 person & 9 & 14 \\
\hline 2 or more unrelated adults & 2 & 4 \\
\hline Lone parent & 8 & 11 \\
\hline Total living in non-couple households & 19 & 29 \\
\hline
\end{tabular}

Source: General Household Survey, 2004

Married or cohabiting couple[4]

Table 2. Types of household: 1979 and 2004

\begin{tabular}{|l|l|l|}
\hline & 1979 & 2004 \\
\hline Household Type & $\%$ & $\%$ \\
\hline Married or cohabiting couple & 65 & 56 \\
\hline 2 or more families & 1 & 1 \\
\hline Total couple households & 66 & 57 \\
\hline 1 person & 23 & 31 \\
\hline 2 or more unrelated adults & 3 & 3 \\
\hline Lone parent & 8 & 10 \\
\hline Total non-couple households & 34 & 44 \\
\hline
\end{tabular}

Source: General Household Survey, 2004.

\section{Solo Living}

2.2 Across Europe, from the early 1970s onwards, there has been a significant, and new, trend away from family households towards one-person households (Hall, Ogden and Hill, 1997). This trend is the result both of compositional changes in the population - increasing numbers of people divorcing or never marrying and of elderly people - and an increasing propensity to live alone, especially amongst young people (Hall et al, 1997). ${ }^{[5]}$ In Britain the proportion of one person households has risen from $17 \%$ in 1971 to $31 \%$ in 2004, and the proportion of people over 16 living alone has risen from $9 \%$ in 1973 to $17 \%$ in 2004. As Table 3 shows, the proportionate increase in solo living is greatest in the $25-44$ age group. This is particularly interesting as it is this age group which, according to dominant norms about family and personal life - hetero-norms - might be most expected to be living in a couple, and having children.

Table 3. Percentage of people living alone, by age: 1973 and 2004 


\begin{tabular}{|l|l|l|}
\hline & 1973 & 2004 \\
\hline Age & $\%$ & $\%$ \\
\hline $16-24$ & 2 & 4 \\
\hline $25-44$ & 2 & 12 \\
\hline $45-64$ & 8 & 16 \\
\hline $65-74$ & 26 & 26 \\
\hline $75+$ & 40 & 47 \\
\hline All 16+ & 9 & 17 \\
\hline
\end{tabular}

\section{"Singleness"}

3.1 If we turn to research on "singleness", as opposed to solo living, we find considerable confusion about the meaning of the category. In registration data and traditional usage "single" refers to marital status - the condition of never having been married - and it therefore includes those who are cohabiting outside marriage. Recently, however, in response to the normalization of heterosexual cohabitation, many researchers, including those responsible for large scale data sets such as the General Household Survey (GHS) and the British Household Panel Survey (BHPS), have redefined the category in terms of "partnership status" rather than marital status. Assuming that there are basically three relationship options, partnership, in the form of marriage or cohabitation, or "remaining single" $[6]$, they operationalize singleness as the state of being "unpartnered", where partnership is equated with co-residence. ${ }^{[7]}$ An example of this shift in the meaning of singleness is seen in Trimberger's (2005) qualitative study of middle class single women in the US. In her first round of interviews she defined as single anyone who was not married (i.e. in terms of marital status), but seven to nine years later, in the second interviews, she defined as single those who were not currently cohabiting or married (i.e. in terms of current partnership status). Whilst the former usage seems clearly outdated in terms of contemporary relationship mores, the latter definition of singleness as remainder is also problematic, because of its conflation of partnership and co-residence. I would suggest that those who are currently generally designated as "single" by most researchers are more accurately understood as "not living with a partner".

3.2 This means that research that reports an "increasing incidence of singleness" (Simpson, 2005) and a "postponement of partnership" (Kiernan, 1999; Ermisch and Francesconi, 2000; Berrington, 2003) actually addresses the increase in the numbers of people who are not living with a partner. So, for instance, Ermisch and Francesconi's (2000) analysis of BHPS data shows that $25 \%$ of women in the $1950-62$ birth cohort were not living with a partner at the age of 24 , rising to $44 \%$ at the same age amongst the 1963-76 cohort, and $40 \%$ of men were not living with a partner at the age of 26 in the older cohort, compared with $48 \%$ amongst the younger cohort.

\section{Non Residential Relationships}

4.1 Whilst sex researchers have long recognized that sexual couplings are not confined to the domestic sphere, it is only relatively recently that sociologists of personal life have begun to recognize that not living with a partner does not necessarily mean not having a partner. A number of different terms have been used to describe the range of non-cohabiting relationships: from the early notion of "commuter marriage" (Gerstel and Gross, 1984; Winfield, 1985), to "weekend couples" (Kim, 2001), "distance relationships" (Holmes, 2004,2006 ) and, the term which is now gaining acceptance in international sociological and demographic literatures, "living apart together", or "LAT", relationships (Winfield, 1985; Levin and Trost, 1999; Ermisch, 2000; Gierveld and Peeters, 2003; Gierveld, 2004; Levin, 2004).

4.2 Researchers are generally keen to distinguish non residential partnerships which are "steady" (Ermisch, 2000, Milan and Peters, 2003) or "regular" (Haskey, 2005) from relationships which are more transitory and less committed. Thus, the 1998 BHPS, which was the first national study in Britain to examine non residential relationships, asked the following question: "Do you have a steady relationship with a male or female friend whom you think of as your 'partner', even though you are not living together?"(Ermisch, 2000). ${ }^{[8]}$ In response to this question, 34\% of men and $42 \%$ of women who were never married, childless and under 35 identified themselves as in non-residential relationships. When relationships of less than 6 months duration were excluded, one third of never married childless women were found to be in non-residential relationships, two-fifths of which were over two years in duration.

4.3 Haskey (2005), reporting the findings of the first Office for National Statistics study of non-residential relationships, conducted via the Omnibus Survey (2002-3), seeks to differentiate the population of those who have a partner who usually lives elsewhere from the more committed group who are "living apart together". He defines a LAT relationship as:

"a relationship, which is understood to include a sexual relationship, between partners who have their own separate address. That is, they usually live at different addresses to each other but they regard themselves as a couple and are recognized as such by others. [....] LAT is, in one respect, similar to co-residential cohabitation in so far as friends and relatives know and accept the relationship. There is also the understanding that, as with cohabitation, 
LAT is generally viewed as monogamous in nature and an arrangement that is more than a temporary, fleeting, or casual relationship" (Haskey, 2005:36)

4.4 Because a relatively large number of teenagers and young people who were still living in their parental home answered in the affirmative to the question "Do you currently have a regular partner?", which was asked of everyone who was not married and living with their spouse, or who was not cohabiting, a more restrictive definition of living apart together was constructed for the Omnibus Survey. This excludes both those who are the children of the household reference person ${ }^{[9]}$ and full-time students, on the grounds that their relationships are more likely to be temporary and they are less able to make a conscious decision about co-residence (Haskey, 2005:43). So, of the 32\% of the men and 34\% of the women aged between 16 and 59 who are not married or cohabiting who have a non residential partner, about two-fifths are children living with their parents, and only about half are described as living apart together. This translates into an estimate that around four million people in Britain (between 1.7 and 2.1 million men and 1.8 and 2.3 million women) in this age group have a partner living elsewhere, and that approximately two million people are in LAT relationships (according to the more restrictive definition) ( 0.9 million men and 1.2 million women). So, whilst both the BHPS research and the Omnibus Survey found that non-residential partnerships are most common amongst younger adults, they are not just a phenomenon of youth, as is shown by Table 4. [10] Indeed, there is roughly the same number of people in non-residential partnerships as are cohabiting. Whilst time series data are not yet available, it seems highly probable, as the numbers of people living alone, divorcing, and not marrying at all are rising, that so too are the numbers in non-residential relationships. ${ }^{[11]}$

Table 4. Residence and Non-Marital Partnership, by age: 2002-3

\begin{tabular}{|l|ll|lc|}
\hline Age & \multicolumn{2}{|c|}{$\begin{array}{c}\text { Non-Residential Partnerships } \\
\%\end{array}$} & \multicolumn{2}{|c|}{$\begin{array}{c}\text { Cohabiting Partnerships } \\
\%\end{array}$} \\
& Men & Women & Men & Women \\
\hline $16-19$ & 26 & 35 & 3 & 6 \\
\hline $20-24$ & 37 & 40 & 13 & 23 \\
\hline $25-29$ & 25 & 25 & 32 & 38 \\
\hline $30-34$ & 22 & 28 & 45 & 33 \\
\hline $35-39$ & 18 & 20 & 39 & 33 \\
\hline $40-44$ & 17 & 16 & 43 & 28 \\
\hline $45-49$ & 18 & 17 & 20 & 22 \\
\hline $50-59$ & 14 & 13 & 28 & 21 \\
\hline A11 & 24 & 26 & 25 & 25 \\
\hline
\end{tabular}

Source: Omnibus Survey (Haskey, 2005:41).

4.5 So, taken together, there is now a powerful body of statistical evidence which suggests that more people in Britain are living longer periods of their lives not just outside marriage and the conventional family, but also outside a co-residential partnership. Very little, however, is known about the meanings that are attributed to living without a co-resident partner by those who do this, and it is to this that I now turn.

\section{Methodology}

5.1 The remainder of the paper draws on research carried out as part of the ESRC Research Group for the Study of Care, Values and the Future of Welfare (CAVA) between 2000 and 2003. ${ }^{[12]}$ The project involved two phases of data collection. ${ }^{[13]}$ In the first phase, in-depth narrative interviews, lasting between one and a half and two and a half hours, were carried out with $5^{[14]}$ people aged between 25 and 60 years old who did not live with a partner. ${ }^{[15]}$ This was followed by second interviews, also in-depth and narrative in orientation, with $24^{[16]}$ of the sample, approximately eighteen months to two years later, which introduced a longitudinal dimension into the research. ${ }^{[17]}$

5.2 Interviewees were drawn from three localities which Simon Duncan and Darren Smith's (2002) analysis of the geography of family and gender formations identify as significantly different in terms of patterns of household and family form, and in gender and family cultures. ${ }^{[18]}$ The localities, all in northern England, were:

- Inner city Leeds: a multi-ethnic urban area characterised by a diversity of gender and family practices, a higher than average proportion of women in the labour force, and a relatively large number of single person and non-couple households;

- Barnsley: a de-industrialized, former coal-mining town, which is more conventional in terms of gender and family relations and traditional in terms of household form; and

- Hebden Bridge: a small town in which alternative middle class, "down-shifted" lifestyles and sexual non-conformity are common, and where there is a significant lesbian population.

5.3 Within these areas interviewees were found by a range of means: they responded to adverts calling for 
participants placed on community notice boards in shops and cafes, in local newspapers and workplace newsletters, and to leaflets which were distributed via GPs' surgeries, self-help and support groups, through adult and further education classes, and hair salons. ${ }^{[19]}$ Some, particularly the lesbian and gay interviewees, were also recruited by snowballing from existing contacts in each of the localities.

5.4 The research sought not to assume in advance which relationships mattered to people, and was designed to elicit narratives of personal life, relationships and experiences of giving and receiving care in which, as much as possible, the interviewee's own meanings and values would be articulated. We began each interview with a "relationship mapping" exercise, in which participants were asked to write the names of everyone whom they felt was significant to them within a series of concentric circles, indicating the nature of the relationship by the use of different coloured pens, and the degree of closeness felt by their proximity to the centre of the circle. This map was then used as a resource during the interview, to ensure that all of the interviewee's significant relationships were discussed. The interview method itself was influenced by Wendy Hollway and Tony Jefferson's (2000) work on the free association narrative interview. Following their suggestion, we used of a relatively small number of open-ended questions, (along the lines of, "can you tell me about...?"), formulated around our main points of interest, in order to give the interviewees time and space to construct their own stories within which meaning and values gradually unfold.

5.5 I then carried out three main modes of analysis of the data thus gathered: (i) a simple quantitative analysis of "who matters" according to the relationship maps; (ii) a conventionally sociological crosssectional thematic analysis, (using a qualitative data analysis package - NVivo), which read across the data set for dominant themes and patterns; and (iii) an in-depth psycho-social analysis of individual cases. ${ }^{[20]}$ Whilst this paper is informed by all three modes of analysis, what is presented is mostly derived from the second.

\section{Description of the Sample}

6.1 The interviewees were selected to include, as far as was possible within the localities, a spread of ages and sexualities: the sample comprised 23 men and 28 women; 24 had children, 27 did not; 46 were white and 5 African Caribbean; 17 were heterosexual men, 19 were heterosexual women, 7 were gay men and 8 were lesbians; and 30 lived alone, 11 with their children and the rest in shared housing 7 in households of two or more unrelated adults, 2 in households of two or more unrelated adults and their children, and 1 with an elderly parent) (see Table 5).

Table 5. Characteristics of Interviewees (at first interview)

\begin{tabular}{|c|c|c|c|c|c|c|}
\hline Locality & Sex & Sexuality & Age & $\begin{array}{l}\text { Have } \\
\text { child/ren }\end{array}$ & Race & $\begin{array}{l}\text { Living } \\
\text { Arrangements }\end{array}$ \\
\hline $\begin{array}{l}\text { Leeds } \\
\mathrm{n}=31\end{array}$ & $\begin{array}{l}\text { Women } \\
\mathrm{n}=28\end{array}$ & $\begin{array}{l}\text { Heterosexual } \\
\text { women } n=19\end{array}$ & $\begin{array}{l}25- \\
34 \\
n=18\end{array}$ & $\begin{array}{l}\text { Yes } \\
\mathrm{n}=24\end{array}$ & $\begin{array}{l}\text { White } \\
\mathrm{n}=46\end{array}$ & $\begin{array}{l}\text { Alone } \\
\mathrm{n}=30\end{array}$ \\
\hline $\begin{array}{l}\text { Barnsley } \\
\mathrm{n}=10\end{array}$ & $\begin{array}{l}\text { Men } \\
\mathrm{n}=23\end{array}$ & $\begin{array}{l}\text { Heterosexual } \\
\text { men } n=17\end{array}$ & $\begin{array}{l}35- \\
44 \\
n=22\end{array}$ & $\begin{array}{l}\text { No } \\
n=27\end{array}$ & $\begin{array}{l}\text { African } \\
\text { Caribbean } \\
n=5\end{array}$ & $\begin{array}{l}\text { With children } \\
n=11\end{array}$ \\
\hline \multirow[t]{4}{*}{$\begin{array}{l}\text { Hebden } \\
\text { Bridge } \\
n=10\end{array}$} & & $\begin{array}{l}\text { Lesbians } \\
\mathrm{n}=8\end{array}$ & $\begin{array}{l}45- \\
60 \\
n=11\end{array}$ & $\begin{array}{l}\text { Under } 18 \\
\text { living } \\
\text { with them }\end{array}$ & & $\begin{array}{l}2 \text { or more } \\
\text { unrelated adults } \\
n=7\end{array}$ \\
\hline & & \multirow[t]{2}{*}{$\begin{array}{l}\text { Gay men } \\
n=7\end{array}$} & & \multirow[t]{2}{*}{$\begin{array}{l}\text { Yes } \\
\mathrm{n}=13\end{array}$} & & $\begin{array}{l}2 \text { or more } \\
\text { unrelated adults } \\
\text { and children }\end{array}$ \\
\hline & & & & & & $\mathrm{n}=2$ \\
\hline & & & & $\begin{array}{l}\mathrm{N}_{0} \\
\mathrm{n}=38\end{array}$ & & $\begin{array}{l}\text { With elderly } \\
\text { parent } \\
n=1\end{array}$ \\
\hline
\end{tabular}

6.2 In terms of socio-economic status, the interviewees can be classified thus: 17 were in managerial or professional occupations, 14 in intermediate occupations, 7 were in routine and manual occupations, 12 were in receipt of benefits (unemployment/ incapacity etc) and 2 were full-time students (see Table 6). [21] The interviewees were, as a group, highly educated; 30 were graduates, of whom 15 also had higher degrees and 4 graduate certificates or diplomas, with the more educated clustered in Leeds, and those with lower level qualifications in Barnsley.

6.3 It should be noted that no claims as to the representativeness of the sample are being made. The interviewees as a group were employed in higher level jobs and were better educated than the population at large, although they were also by no means exclusively middle class and university educated. Hall, Ogden 
and Hill's (1997) research on one person households in England between 1971 and 1991 does, however, suggest that those who live alone (the largest group of those who are not in co-residential partnerships) are skewed towards the higher socio-economic groups. This is particularly so for women. Hall et al (1997) also note that both men and women living alone have higher unemployment rates and are more likely to be described as permanently sick than the population at large. Thus, they conclude, there seems "to be much greater polarization among those living alone between those employed and unemployed, and those permanently sick or well, than in the total population" (1997:172). This casts a favourable light on the sample, suggesting that the skewing towards higher social classes, and the relatively large numbers in receipt of benefits might mirror the wider population of those who are not living with a partner.

\section{Diverse Practices of Partnership}

7.1 Because they did not live with a partner, the people interviewed in this research would, as I have suggested above, be considered by many social researchers to be single. However, the relationship maps they produced and the stories they told in interview suggested that many were engaged in a range of sexual/ love relationship practices which are not captured by the conventional tripartite categories of single/ married/ cohabiting. Just over half (26) of the first round interviewees were not in a sexual/ love relationship at the time of interview ${ }^{[22]}$, whilst 25 were engaged in some form of sexual/ love relationship. [23] This former group might reasonably be referred to as "single", and remain largely outside the scope of this paper. The latter group, on whom I focus in the paper, I will refer to as "partnered", because they all reporting having a sexual/ love partner.

7.2 A close analysis of the interviews suggests that amongst the partnered interviewees there was considerable variation in terms of relationship practices and mentalities. ${ }^{[24]}$ If we seek to distinguish between those in "steady" or "regular" non residential partnerships and those whose relationships are more transitory or casual as Haskey (2005) and other researchers have done, we find that 22 were involved in some form of "couple" relationship (whom I will refer to as "coupled"), in which there was a sense of an ongoing entity composed of two parties and a degree of recognition of this from others. Three of the 25 were engaged in casual sexual partnerships (the "casually partnered") and did not have such a sense of ongoing commitment to each other. ${ }^{[25]}$ It is this former group - the coupled - whom Haskey (2005) would describe as engaged in LAT relationships because "they usually live at different addresses to each other but they regard themselves as a couple and are recognized as such by others" (Haskey, 2005:36). These relationships ranged in duration from a few weeks to 18 years at the time of first interview, with the majority of them over a year old (see table below).

Table 6. Duration of couple relationship (at $1^{\text {st }}$ interview)

\begin{tabular}{|l|c|c|c|c|c|c|}
\hline $\begin{array}{l}\text { Duration of couple relationship } \\
\text { (at } 1^{\text {st }} \text { interview) }\end{array}$ & $<2$ months & $2-12$ months & $\begin{array}{l}1-3 \\
\text { years }\end{array}$ & $\begin{array}{l}4-6 \\
\text { years }\end{array}$ & $\begin{array}{l}7-10 \\
\text { years }\end{array}$ & $\begin{array}{l}>10 \\
\text { years }\end{array}$ \\
\hline Number of interviewees & 1 & 9 & 5 & 3 & 1 & 3 \\
\hline
\end{tabular}

7.3 Of the nine coupled interviewees who were interviewed twice, four had split up with their partners in the eighteen months to two years between interviews. At the time of re-interview, seven of the nine were coupled, two with new partners, one was single, and one was engaged in a casual partnership. None had moved in with their partner.

7.4 Surprisingly, given the emphasis on "commuting" (Gerstel and Gross, 1984; Winfield, 1985) and "distance" (Holmes, 2004) in previous research on non-residential relationships, the majority of nonresidential relationships reported in the research were between people living in the same locality. Sixteen of the first round interviewees were involved with partners who lived in the same town or city, with three in relationships with people who lived approximately an hour away, and seven were in long distance relationships with partners who lived over two hundred miles away, three of whom were overseas. [26] Whereas those in local relationships were diverse in terms of socio-economic status and the localities in which they lived, the "long distance lovers" were a much more homogeneous group. All of those in long distance relationships had higher degrees, all but one of them lived in Leeds, with the other living in Hebden Bridge, all but one were in professional or managerial occupations, and four of them were academics. This resonates with research which suggests that dual career, high skilled professional couples, and particularly academics, are often involved in long distance relationships (Gerstel and Gross, 1984; Green, 1997; Holmes, 2004). However, the predominance of relationships being between people living in the same locality is an important finding which raises questions about the explanatory status accorded to the exigencies of employment in previous discussions of non-residential relationships.

\section{Orientations towards (Non)Cohabitation}

8.1 Levin (2004), who has conducted the largest qualitative study of LAT relationships amongst adults, divided her Norwegian and Swedish sample of 100 into two groups, on the basis of attitudes towards their non-cohabitation: those who would have liked to live together but had decided not to, and those who would not live together even if they could. The former group was composed of those who chose not to cohabit because of a sense of responsibility to care for others (particularly children, but also elderly or disabled parents), who would be disturbed if the partners decided to move in together, along with those who worked or studied in different places and did not wish to relinquish either their individual careers or the relationship. The latter group contained those who had previously been married or had cohabited, and did not want to find themselves facing another painful separation, a group of retired people who do not wish to disrupt their 
own sense of personal history or jeopardize their children's inheritance by moving in with a partner, and a group of people who had previously cohabited who decided to physically separate, whilst seeking to maintain their relationship. Unfortunately Levin does not give any indication of the numbers of her interviewees who fell into each group, but her work offers a useful point of comparison for my, admittedly much smaller, sample.

8.2 The interviewees in my research cannot be categorized dichotomously in terms of the two groups suggested by Levin. Rather, their orientations towards cohabitation suggested three groups: a small group who wished to live with their partner but who had decided not to (the regretfully apart); a larger group who were clear that they did not want to live with their partner (the gladly apart); and the largest group who had not made an explicit decision about the issue (the undecidedly apart). Perhaps because, unlike Levin's sample, they had not volunteered to take part in the study self-identifying as in LAT relationships, the interviewees in my research were less likely to have engaged in conscious decision-making about the noncohabiting dimension of their relationships than Levin's subjects. There were no interviewees who, as in Levin's (2004) research, said that they unambiguously wished to cohabit but did not do so because of caring responsibilities.

\section{The Regretfully Apart}

8.3 The small group of three who were regretful about not living with their partners had all previously cohabited with their current partners. Two of them, both academics with higher degrees, had actively decided to move apart for career reasons; for these "dual career couples", like those studied by Gerstel and Gross (1984), Green (1997) and Holmes (2004), work took precedence over living together. They had a clear sense of themselves as part of a couple, but also were committed to their own individual careers, and were in heterosexual relationships with partners who were similarly committed. Expectations of geographical mobility were embedded in their relationships and built into their career choices. All of them would rather live with their partner, but found positive aspects to not living together, for themselves and their partner as individuals, and for their relationships, and all hoped to live together again in the future.

8.4 Teresa was, formally at least, the most conventionally coupled interviewee in the research: she was the only interviewee who was married to her current partner, the only one to put only her partner in the inner most circle of her relationship map (every one else had some combination of partner, children and friends in this circle), and she was the only interviewee who expressed distress at not living with her partner. She had been married for six years at the time of the interview, having met Peter in Eastern Europe, in her country of origin. She moved to the UK to be with him, and enrolled on a PhD programme. They lived together for three years, with a gap of a year in the middle when he spent time abroad on sabbatical and she remained in the UK studying for her $\mathrm{PhD}$, until he was offered a job at a prestigious university several hundred miles away. Although he was worried about the impact his moving away might have on their relationship, she insisted that he did so, citing her concern that the relationship would sour if he felt that his development as an individual was hampered because of it:
He was very concerned about moving away from me. But, I was at the end of my Ph.D. and I said to him, 'Look, now is the time to move, because, I am...I'm not in a senior position, it's very easy to get a junior job, and $X$ is a place where you get lots of jobs.' And for him, moving to $X$ University was a very big thing. I mean, everybody wants to work at $X$ University. And... And he, he was quite worried. He was about to turn it down, because he just didn't want to go away. And you know, I just thought, if you stop your career on account of your relationship, Pete, you will resent it, and the relationship is going to go bad. And I must say that it's...it's been really good. It's not as hard as I imagined it would be (white heterosexual woman, 34, Leeds)

8.5 Although they speak on the phone about five times a day and spend most weekends together, and often manage to extend these weekends by a couple of days, living apart was having an emotional cost for Teresa, such that she was unable to sleep in their shared bed whilst he was away. However, she consoled herself with the thought that the situation was temporary, and with her knowledge that Peter was fulfilled in his work.

8.6 Philip, who had also been with his partner for six years at the time of the interview, appeared to be less dramatically affected by living apart from his partner. He was one of only two interviewees who were in relationships who did not place their partner in the innermost circle on their relationship map. He and his partner, Rebecca, had been living together for two years when he was offered a job in a different city and shortly afterwards she was offered a job overseas. Their posts were two year contracts and so their intention was to move back to the same city at the end; but it did not work out like that. His contract was extended by a year, and she was promoted, and at the time of interview their future living arrangements were unresolved. There were positive things about living apart:

[I]t is really nice pleasing yourself and living the way you want, and ...you can live in whatever mess or surroundings you want really. You can cook when you want, you eat what you want, and you don't think... Well, Rebecca's a vegetarian, we would kind of do something together. It is nice being selfish for a while (white heterosexual man, 33, Leeds)

8.7 But, his preference would be to live together again, and his desire to live with his partner had a moral dimension, based on his belief that in living with someone "maybe you develop more as a person, you're more rounded, you think about people more. Instead of tending to just go off on your own tangents, because you're in a kind of isolated job, and your isolated life, you can just do what you damn well please". 
8.8 In different ways, then, both Teresa and Philip placed a high value on the couple relationship, and, regretting their non-cohabitation, held to the most conventional models of coupledom amongst the interviewees. Whilst they had chosen to disrupt the normative model of coupledom by choosing to live apart, they hoped to be reunited with their partners in one place at some time in the future.

8.9 In contrast, the other member of this group, a gay man who had been with his partner for thirteen years, told a story of regret that emphasized the lack of choice that he had experienced in his decisions about cohabitation, and in which there was no shared desire to live together in the future. Craig and his partner, who lived an hour away, both had a history of insecure housing, during which they had cohabited for two periods of over a year, when each, in turn, had become homeless. Although the second period of living together in Craig's one-bedroom flat was not easy, Craig had wanted them to continue to cohabit. But they both believed it was necessary for them each to have their own homes because Craig was HIV positive, and they understood that when he died, as he expected to do, the tenancy of his council flat would not pass to his partner. ${ }^{[27]}$ Craig was angry about the homophobia that underlay housing policy, which had made his partner move out. His life had been changed by his HIV + diagnosis, and then again by the arrival of combination therapy, which meant that he was facing a future that he had all but given up on. He expressed regret that his relationship had not developed in the way that he had wanted, and that his partner now did not want to live with him.

I'm quite disappointed and quite resentful really [...] because now that things have changed, I'm feeling that things could have been so different. We could have been buying a house together. And that's not going to happen. Too much water's gone under the bridge. We've lived apart for too long. [...] But why should he give up the freedom, you know, being able to do as he wants? It's not an ideal situation, really. It's certainly not what I would call a relationship that's like other people (white gay man, 32, Leeds).

8.10 Craig's story highlights the impact of forces beyond the control of an individual, in this case, illness and discriminatory social policy, on the course of a relationship and on decisions not to cohabit, and modulates the emphasis on individual careers and choice in the accounts of the other regretfully apart interviewees.

\section{The Gladly Apart}

8.11 At the opposite end of the spectrum of orientation to cohabitation were the eight interviewees who were clear that they would not live with their partner, even if they could. Of these, five lived in the same locality as their partners, two were in long distance relationships, and one lived an hour from her partner. Ranging in age from 29 to 60, this group all lived either alone or, in two cases, with their children, and gave the impression of being settled in their homes and their lives. All but one of them had been with their partners for over a year, three of them had been in their relationship for over four years, of whom two for over ten years. One woman had two children with her non-cohabiting partner of ten years, and another was planning to get pregnant. Their narratives expressed a strong sense of individual agency, and a determination to be in control of their own lives. Whilst their partners were important to them, this group of interviewees shared a more or less explicitly articulated commitment to maintaining separateness from their partners.

8.12 This commitment to separateness within coupledom was often framed in terms of a psychic need for time and space for themselves, in the context of demanding work lives which took up considerable emotional energy. For instance, Brad, a white gay man, who worked in a caring profession and had been with his partner for 18 months at the time of first interview, expressed his desire for time on his own:

I think I keep a distance between us really. Because I don't want that, sort of, he would want much more than I would [...] And, I don't know really why I keep a distance between us. I really just wanted to have my own, part of my own life. [...] He would spend all his time with me if he could, and I wanted time on my own. Because I'm used to having that [...] I just feel that there are people making demands on me all day and so there are times when $\mathrm{I}$ just want to sit and do what I want to do. And just be on my own for a bit, you know. After certain shifts and things, you just want to sit, and so that's another reason I think I've tried to put some distance there (white gay man, 40, Leeds)

The more material issue of control over separate domestic space was also an important consideration for some, such as Helen, who saw themselves as choosing to live apart:

I'm so used to having my own space how I like it. And I like that. I don't want... The phrase that I use, I don't want a man messing it up. I don't want to come home to somebody of an evening. I like coming home and going, phew! My space. I don't want the extra frustration of going, these aren't my dishes. I don't want to go, oh there's his stuff on the floor again. Those are the additional things about living together which would disrupt our relationship, and I don't see that we need to have those things (white heterosexual woman, 37, Leeds)

8.13 Helen was not alone in her desire to protect her relationship from cohabitation. Alongside the desire to protect the self, and the space around it, several of this group spoke of wishing simultaneously to protect their relationship, regarding the close, consistent co-presence of cohabitation as potentially risky:

I think I'm very frightened that living together would knacker the relationship in the long term (white heterosexual man, 49, Leeds) 
8.14 One interesting outlier in this group was the oldest person interviewed in the research, Iris, who was 60 . She shared a home with her elderly father and had been happily involved in a non-residential relationship with her male partner for 17 years. However, it was not her sense of obligation to her father that prevented her from choosing to live with her partner, but her commitment to her work, which she regarded as her priority. She had no regrets about her choice of work over cohabitation and marriage, having enjoyed both her career and her relationship for many years. But, facing the prospect of retirement in the near future, which would mean that she would have more time to devote to her relationship, she was now contemplating marriage and moving in with her partner. Iris's narrative was strikingly different from the other interviewees in its lack to attention to her own needs, and in her belief that her career militated against a properly committed relationship is suggestive of an older normative model of women's employment which posed work against family life.

\section{The Undecidedly Apart}

8.15 In contrast to the regretfully apart and the gladly apart, for whom the expression of some degree of agency and choice about not living with their partner was almost universal, the largest group of interviewees who were in couple relationships (11 of 22) had not made an explicit decision about whether to cohabit or not. For this group, coupledom took a less strategic, thought-out and negotiated form than is suggested by Levin's research. For the two people in this group - a gay man and a heterosexual man - who were in long distance relationships and who had been involved with their partners for two and a half and four years respectively, cohabitation was not on the agenda. In part, their embeddedness in work and social relations in Leeds meant that they had not considered cohabitation as a serious possibility, but it was not just this. Both seemed to be very attached to their partners, emotionally and sexually, and greatly valued the time they spent together, but this did not create any impetus to consider living together. Their relationships were not constructed within a framework in which living together was something about which to decide.

8.16 The rest of the group, however, were, with one exception, all in local relationships, so it was not work or previously established lives in different places that were keeping these couples apart. Rather, their noncohabitation was tied up with their broader orientations towards their relationships, which were more contingent and less settled. Eight had been involved with their current partner for less than a year and one for two years. Amongst this sub-group, most expressed some degree of ambivalence about their current relationship. At one end of the continuum, three interviewees framed their non-cohabitation in terms of "not being ready yet" because they were not completely sure about the relationship, but were working with an assumption that they might cohabit in the future. Sid was the clearest of these that cohabitation was his direction of travel, and he was the only interviewee in the study who saw himself as being in the precohabitation phase of his relationship:

Q: So with Erica the dynamic right now is separate living spaces?

Sid: Yeah. And I think it's nice to have two places to stop at as well, and you still get a bit of your own space. I think part of it's commitment. I'm willing to do it, but I'm happy where I am, and also there's a monetary thing, in that there's quite a lot of things I want to do this year, such as a holiday and things,. And I wouldn't want to have to move, cos obviously there's a lot of added expense. And that's why I'd like to leave it longer, to make sure I'm 100\% sure. I'm sort of like 98\% sure now, but it's that extra couple of percent before I throw myself in the deep end. I think about things too much, rather than just doing it, you know. That's my problem [laughs].

Q: So what do you think will happen in the future then with that living arrangement?

Sid: I could definitely see us living together next year. (white heterosexual man, 36, Leeds)

8.17 At the other end of the continuum, however, were those who had real doubts about their relationship, and did not entertain, therefore, the possibility of cohabitation with their current partner. Margaret, for instance, who describes her relationship with Bob as "a calm easy going set up", says:

I'm so aware that we are at different stages [...]. It could be the parting of the ways in a few months. We're talking about it. It will be sad because we do get on well, and we are able to be quite calm together. We don't have many highs and lows. We are fairly steady [laughter], but sometimes I think it doesn't add up to much. And sometimes I think, no, that's quite healthy, in its own way, you know. We're both looking for things, rather than finding them, at the moment. We're not actually in positions that we want to really be in long term, and I think that gives us a good friendship in a way too - sort of empathy - and it means we are able to talk about ourselves as individuals and our paths rather than feeling that it's got to be us together. We don't live together (white heterosexual woman, 49, Hebden Bridge).

Indeed, at the time of interview, Margaret was actively considering the possibility of moving abroad to live with another man.

8.18 Somewhere between Sid's $98 \%$ certainty that he would cohabit with his partner and Margaret's prediction that she would split up with hers, were most of the other undecidedly apart, who were just living in the present, with no plans to consider cohabitation.

8.19 In common with some of the gladly apart, all of the undecidedly apart interviewees, even those who thought they might live together in the future, shared a wariness about cohabitation. They spoke of the riskiness of living together, and some were quite clear that they were scared of it. Almost universally, they identified the source of their anxiety in their experiences of the ending in a previous relationship, in which they had been hurt or had lost their home. Past relationships had left emotional legacies of mistrust and 
risk aversion which impacted upon current relationships and the sense of future possibilities. Many of them showed a high degree of self-reflexivity in discussing how this impacted upon their current relationship, and made them determined to try to avoid this happening again. For instance, Sid explained his need to wait until he was "100\% sure" as follows:

I think I'm frightened of being hurt, whereas she's willing to just go with it and see what happens. We do love each other and she realised she loved me quite a bit before I realised it with her. But then, that's from my past experience.

8.20 And Margaret, who had not lived with anyone for 28 years, described her "carefulness":

Since my marriage split up, I think I'm very careful about going the full hilt in a relationship, about going "OK, I will take on you and us completely", you know.

8.21 Practical and material concerns about housing security were particularly productive of a degree of caution about cohabitation. Tim was ambivalent about living with his partner, torn between the desire to do so, and the fear of losing his home:

I probably would move in with her, but, I don't want to because - I'm a bit wary about relationships. I think she is as well, because she's had like bad relationships in the past. So, there is all that love there and it's from her as well. We have spoken about it, and there's enough love to actually probably move in together and cohabit but I'm scared [...] I am totally committed to her, but it'd be me moving in with her and I've got my flat and I don't - if something did happen you know l'd just be starting off from scratch again and so well that's basically why I don't live with her (white heterosexual man, 26, Hebden Bridge).

8.22 And for LJ, "not rushing anything" ("anything" being living together) with her partner was related to her worry that she would lose control of her home:

It took me a long time to get out of my marriage and sort everything out. So this is my home, and it's taken me a long time to get this, and I'm wary about anybody else having any kind of claim on my home (white lesbian, 40, Hebden Bridge).

\section{Individual and Relational Contexts in Understanding Orientations to (Non)Cohabitation}

9.1 As we have seen, across the dataset the coupled interviewees spoke of their non-cohabitation primarily in terms of their own personal needs and desires, both emotional/ psychic and practical/ material, and/ or with reference to the current state of their sexual/love relationship. Many also cited the impact of their experiences of past relationships. In other words, orientations towards (non) cohabitation were expressed in terms of either an individual logic or a relational logic, or, most commonly, both.

9.2 However, the stories that interviewees told about their non-cohabitating relationships must also be understood within the broader context of the interview, which focused on a range of other relationships in addition to sexual/ love relationships - relationships with family, friends, neighbours and work colleagues. Particularly important here was that the wider narratives offered by interviewees spoke of a significant decentring of the sexual/ love relationship within their personal lives, and a centring instead on friendship (see Roseneil and Budgeon, 2004). There was a pronounced tendency, amongst both interviewees who were involved in sexual/love relationships and those who were not, to de-prioritize sexual/ love relationships and to place far more importance on friendship than conventional relationship mores dictate. Against the dominant heteronormative emphasis on finding and keeping a life-long conjugal partner, there was a widespread belief that such relationships are increasingly rare, and that a happier, more secure life is to be created by investing time and energy in maintaining friendships. This disinvesting in potentially risky sexual/love relationships and the prioritizing of friendships, which interviewees tended to regard as more stable and reliable, is an important part of the relational context within which lives were lived outside cohabiting relationships.

9.3 The significance of children in the formation of interviewees' orientations towards cohabitation must also be considered. Others who have researched LAT relationships (Levin, 2004), the re-partnering decisions of the divorced (Smart and Neale, 2003), and step-families (Ribbens McCarthy, Edwards and Gillies, 2003) have all highlighted the way in which the needs of children are given priority by many, if not most, parents when facing decisions about cohabiting with a partner. In this study, however, of the thirteen interviewees who had children under 18 living with them, only three were in non-cohabiting couple relationships; nine were single, and one was in a casual partnership. I explore elsewhere (Roseneil, 2007) the significance of children in the personal lives of the interviewees. Suffice to say that the presence of children was an important factor in most interviewees' orientations towards sexual/love relationships, but this was particularly the case for those who were single. The presence of children was identified by single interviewees as giving rise to a considerable degree of caution about such relationships, and particularly about the prospect of cohabiting with a partner. But only one of the three coupled parents placed any significant emphasis on the role played by their children in their relationship decisions and orientations.

9.4 For the undecidedly apart parent, LJ, a white lesbian from Hebden Bridge (mentioned above), it was her concern about the security of her home rather than expressly that of her children that was a consideration in thinking about cohabitation. And one of the gladly apart parents, Kelly, a black heterosexual woman from Leeds, who had never lived with her partner (the father of her children), spoke of her desire to live separately in terms of her need for her independence. Cohabitation had never been on the agenda and she did not suggest that her children were relevant to her feelings about cohabitation. The one coupled parent for whom children were more clearly a factor in her orientation toward cohabitation was Carol, a white 
heterosexual woman from Barnsley. But even she did not frame her story solely in terms of her children; her own needs were also important. She had moved in with her partner on leaving her husband, but moved out again as soon as she was able to buy a small house for herself and her daughters, who were unhappy living with her "Jekyll and Hyde" like new partner. She saw his volatile temper and ongoing mental health problems having negative effects on both herself and her children. She was perhaps relieved rather than glad to be living apart from her partner at the time of the first interview, and expressed her desire to end the relationship with him in the near future. By the second interview she had done this, and had embarked on a new relationship, with a man with whom she felt she might one day like to live, once all their children had left home. In the meantime, she was positive about many aspects of her non-residential relationship.

\section{Concluding Comments}

10.1 The people interviewed in this research pose a challenge to the assumption, shared by much of sociology, social research and public culture, that not living with a partner means being single, and that entry into cohabiting coupledom is the expectation and aim of almost everyone. Across differences of socio-economic class, gender and sexuality, and with only a few exceptions, cohabitation was not constructed as an unequivocally desired goal by the coupled interviewees. Every one of them, even those who were regretfully apart, was positive about some aspects of not living with their partner, and almost all regarded a non-residential relationship as a valid way of living in its own right, not as a stepping stone on the journey towards a "proper" relationship.

10.2 Underlying these orientations was a widespread and profound ambivalence about the cohabiting couple form. Many of the interviewees' sexual/ love relationships were being conducted outside a paradigm of "settling", and were very much works in progress - understood and accepted as contingent, unresolved and fluid. I am aware here that this description has resonance with Giddens' (1992) notion of the "pure relationship" and Bauman's (2003) metaphor of "liquid love". Whilst I have been critical elsewhere of what I have called the "patriarchal pessimism" (Roseneil, 2004) of Bauman's account of contemporary intimate life, with its nostalgia for bygone days of stable families and secure communities, the processual, undecided character of many of the non-residential relationships in this study cannot be ignored. That said, there was also a considerable minority of interviewees who were in long-term, settled relationships, and who were also challenging the assumed contiguity of coupledom and cohabitation.

10.3Although based on a small sample, this intensive study of the practices and values of people who are not living with a partner offers new insight into the ways in which coupledom is being re-worked and intimacy transformed in contemporary Britain. It provides evidence of a new orientation towards sexual/love relationships emerging amongst a particular, but growing, sector of the population, and suggests that both more empirical research and new theorizing of the relationship between partnership and household would be timely.

\section{Notes}

${ }^{1}$ These figures refer to all persons in the population, not just adults.

${ }^{2}$ These figures are the sum of statistics relating to households of one person, two or more unrelated adults and lone parents. http://www.statistics.gov.uk/downloads/theme_compendia/ GHS04/GHS04_3Householdsfamiliesandpeople.xls

${ }^{3}$ This is percentage of all people in the population (unweighted sample of $20,000+$ ).

${ }^{4}$ It should be noted that whilst GHS statistics relating to cohabiting couples contain a small number of cohabiting same-sex couples from 1996 onwards, it is highly likely that these are under-counted, and that many same-sex couples appear in the statistics as "unrelated adults".

${ }^{5}$ Whilst analyses of longitudinal data such as BHPS (by Wassoff et al, 2005) and the ONS Longitudinal Study (by Chandler et al, 2004) show that individuals move in and out of living alone, sociologists working with these data emphasize different dimensions of their findings. Wassoff et al (2005:221) stress that transitions in and out of solo living are about twice as common as living alone permanently, with only $30 \%$ of the $23 \%$ of people (aged between 30 and 74) who have lived alone at some point between 1991 and 2001 living alone throughout the period 1991-2001, compared with 70\% of this group who had moved into or out of solo living. In other words, only $7 \%$ of the cohort lived alone for the whole period. In contrast Chandler et al's (2004) analysis highlights that as well as living alone becoming more common, younger cohorts are more likely to live alone at some stage than older cohorts, and are more likely to live alone for long periods of time. They conclude that once a person lives alone they are more likely to continue to live alone than in any other arrangement (2004:6.1).

${ }^{6}$ Examples of this widespread assumption are Kiernan (1999), Ermisch and Francesconi (2000), Jamieson et al (2002), Simpson (2005). It should be noted, however, that elsewhere Jamieson et al (2003) recognize that "young people who are 'single' in the sense of not living with somebody, may, of course, nevertheless be 'in a relationship"' (2003: 138).

${ }^{7}$ Further confusion in the category is produced by some researchers including the divorced and separated in the category of single if they have not entered a new cohabiting partnership, whilst others do not.

${ }^{8}$ The sexual nature of this relationship is assumed rather than being made explicit, as is typical in social 
research. Haskey (2005) argues that using the word "partner" and "regular", as is done by ONS in the 2002-3 Omnibus Survey, is intended and received as suggesting a sexual relationship. The 2001 Canadian General Social Survey is even more coy, asking "Are you in an intimate relationship with someone who lives in a separate household?" (Milan and Peters, 2003:3).

${ }^{9}$ The Household Reference Person is, for ONS, the householder in a one person household, and the person with the highest income where there are joint householders, or the older, where incomes are equal (Haskey, 2005:37).

${ }^{10}$ Research in the Netherlands (Gierveld, 2004) suggests that LAT relationships are more common
amongst the over 50 s who are divorced or bereaved than cohabitation.

${ }^{11}$ In Sweden, however, there are data which suggests an increase in the prevalence of LAT relationships: from $6 \%$ of those aged $18-74$ who were neither married nor cohabiting in 1993 , to $12 \%$ in 1998 , to $14 \%$ in 2001 (Levin, 2004).

${ }^{12}$ For further information about CAVA see http://www.leeds. ac.uk./cava Funded by the ESRC (ref. M56281001), the grant holders were Fiona Williams, Carol Smart, Alan Deacon, Sasha Roseneil, and Simon Duncan.

${ }^{13}$ The first phase researcher was Shelley Budgeon and the second stage was Jacqui Gabb. The majority of the first round interviews were conducted by Shelley Budgeon, with a small number by the author. All of the second round interviews were conducted by the author.

${ }^{14}$ In earlier publications a sample of 53 was reported, but further analysis of the data has led to the exclusion of two interviews on the grounds that date of birth and place of residence had been misrecorded, and were actually outside the sample criteria.

${ }^{15}$ This age band was chosen in order to exclude young adults whose lives might be more likely to still be in considerable flux and who were less likely to have made active decisions about issues of partnership and residence, and elderly adults who were more likely to have experienced bereavement. It is from the age of 25 that cohabitation becomes more common than non-residential partnership amongst those who are not married (Haskey, 2005), which means that the study focuses on those who are leading less normative lives.

${ }^{16}$ One of the re-interviewees was excluded from the analysis on the grounds that place of residence had been misrecorded.

${ }^{17}$ As we had not kept in contact with interviewees after the first interview, the second phase of interviews missed those who had moved house in the interim. 15 of 31 were re-interviewed of the Leeds sample, 5 of 10 from Barnsley, and 4 of 10 from Hebden Bridge.

${ }^{18}$ This mapped spatial differences in gender and family cultures according to four indices - a Motherhood Employment Effect, a Family Conventionality Effect, a Traditional Household index and a Family

Restructuring index (see Duncan, 2000, a, b, c). Roseneil (2007) contains a more detailed discussion of the differences between the localities in terms of patterns of intimacy and personal life than is possible in this article.

${ }^{19}$ In seeking to recruit our sample we stated that we wanted to talk to people who "were not part of a conventional couple who live together", and that we were interested in changes in personal relationships and family life, and particularly in friendship.

${ }^{20}$ See Roseneil (2006) for an example and discussion of using psycho-social methods to study contemporary personal life.

${ }^{21}$ This classification scheme is based on the three class version of the National Statistics Socio-Economic Classification (NS-SEC). http://www.statistics.gov.uk/methods_quality /ns_sec/default.asp. Two further groups have been added to this (in receipt of benefits/ unemployment/ incapacity; full-time student), in order to specify current socio-economic situation, rather than classifying according to last occupation or parental occupation, as required by NS-SEC.

${ }^{22}$ Of the 26 who were not in a sexual/ love relationship at the time of first interview, 7 were from Barnsley, 2 from Hebden Bridge and 17 from Leeds.

${ }^{23}$ Of the 25 who were involved in some form of sexual love relationship at the time of first interview, 3 were from Barnsley, 8 from Hebden Bridge and 14 from Leeds.

${ }^{24}$ Lewis (2001) offers the important distinction between behaviour and mentalities in her study of married and cohabiting couples.

${ }^{25}$ Of the 3 who were engaged in casual sexual partnerships at the time of first interview, one was from each locality. 
${ }^{26}$ One interviewee was involved with two people, one of whom lived locally and the other overseas.

${ }^{27}$ It was only in 1999 that the House of Lords ruled that same-sex partners should be treated as family and should have the right to succeed to a tenancy. The 2005 Civil Partnership Act served to formally equalize the housing rights of registered civil partners with those of married couples, and those of same-sex couples living together as if they were civil partners with those of unmarried opposite-sex cohabitants.

\section{References}

BAUMAN, Z. (2003) Liquid Love Cambridge: Polity.

BERRINGTON, A. (2003) "Change and Continuity in Family Formation among Young Adults", Social Statistical Sciences Research Institute, University of Southampton, Working Paper 03/04.

CHANDLER, J., M. Williams, M. Moconachie, T. Collett and B. Dodgeon (2004) "Living Alone: Its Place in Household Formation and Change", Sociological Research Online Vol. 9, Issue 3.

http://www.socresonline.org.uk/9/3/chandler.html

DUNCAN, S. (2000a) "The Use and Abuse of Locality Research", CAVA Workshop Paper No. 17a http://www.leeds.ac.uk/cava/papers/ workshoppapers.htm

DUNCAN, S. (2000b) "Choosing Case Study Areas for Strand 3 Research - localities and neighbourhoods", CAVA Workshop Paper No. 17b http://www.leeds.ac.uk/cava/papers/ workshoppapers.htm

DUNCAN, S. (2000c) "Variations in Parenting and Partnering at the Local Level" CAVA Workshop Paper No. 17c http://www.leeds.ac.uk/ cava/papers/workshoppapers.htm

DUNCAN, S. and D. Smith (2002) 'Geographies of family formations: spatial differences and gender cultures in Britain', Transactions, 27, 471- 493.

DUNCAN, S, A. Barlow, and G. James (2005) "Why don't they marry? Cohabitation, commitment and DIY marriage" Child and Family Law Quarterly Vol.17. No.3:383-398.

ERMISCH, J. (2000) "Personal Relationships and Marriage Expectations: evidence from the 1998 British Household Panel Survey" Institute for Social and Economic Research Working Paper August 2000, University of Essex.

ERMISCH, J. and M. Francesconi (2000) "Patterns of Household and Family Formation", in R. Berthoud and J. Gershuny (eds) Seven Years in the Lives of British Families Bristol: The Policy Press.

GERSTEL, N.R. and Gross, H. (1984) Commuter Marriage: a study of work and family London: Guildford Press.

GIDDENS, A. (1992) The Transformation of Intimacy: Sexuality, Love and Eroticism in Modern Societies Cambridge: Polity.

GIERVELD, J. de J. and A. M. Peeters (2003) "The interweaving of repartnered older adults' lives with their children and siblings", Ageing and Society, 23: 187-205.

GIERVELD, J. de J. (2004) "Remarriage, unmarried cohabitation, livng apart together: partner relationships following bereavement or divorce" Journal of Marriage and Family, 66:236-243.

GREEN, A.E. (1997) "A Question of Compromise? Case Study Evidence on the Location and Mobility Strategies of Dual Career Households" Regional Studies, 31(7):641-57.

HALL, R., P. Ogden and C. Hill (1997) "The Pattern and Structure of One-Person Households in England and Wales and France", International Journal of Population Geography, Vol. 3:161-181.

HASKEY, J. (2005) "Living arrangements in contemporary Britain: Having a partner who usually lives elsewhere and Living Apart Together (LAT)", Population Trends 122, 35-45.

HOLLWAY, W. and T. Jefferson (2000) Doing Qualitative Research Differently London: Sage.

HOLMES, M. (2004) "An equal distance? Individualisation, gender and intimacy in distance relationships" The Sociological Review:180-200.

HOLMES, M. (2006) "Love Lives at a Distance: Distance Relationships over the Lifecourse", Sociological Research Online (this issue).

JAMIESON, L., M. Anderson, D. McCrone, F. Bechhofer, R. Stewart and Y. Li (2002) "Cohabitation and Commitment: partnership plans of young men and women", The Sociological Review, 356-377.

JAMIESON, L., R. Stewart, Y. Li, M. Anderson, F. Bechhofer and D. McCrone (2003) "Single, twentysomething and seeking?" in G. Allan and G. Jones (eds) Social Relations and the Life Course: Age, Generation and Social Change London: Palgrave 135-154. 
KIERNAN, K. (1999) "Cohabitation in Western Europe", Population Trends 96:25-32.

KIM, S.C. (2001) "'Weekend Couples' amongst Korean Professionals: an ethnography of living apart on weekdays" Korea Journal 41(4): 28-47.

LEVIN, I. (2004) "Living Apart Together: a new family form" Current Sociology Vol. 52, No.2: $223-240$.

LEVIN, I. and J. Trost (1999) "Living Apart Together" Community, Work and Family 2(3): 279-294.

LEWIS, J. (2001) The End of Marriage? Individualism and Intimate Relations Cheltenham: Edward Elgar.

MILAN, A. and A. Peters (2003) Couples Living Apart Canadian Social Trends, Statistics Canada catalogue no. 11-008: 2-6.

RIBBENS MCCARTHY, J., R. Edwards and V. Gillies (2003) Making Families: moral tales of parenting and step-parenting Durham: Sociology Press.

ROSENEIL, S. (2004) 'Sutured Selves, Queer Connections: Intimacy at the Cutting Edge of Individualization', CAVA Symposium "Rethinking Family Lives", Weetwood Hall, Leeds, December 2004.

ROSENEIL, S. and S. Budgeon (2004) 'Cultures of Intimacy and Care Beyond the Family: Personal Life and Social Change in the Early Twenty-First Century"', Current Sociology, Vol. 52, No. 2, 135-159.

ROSENEIL, S (2006) 'The Ambivalences of Angel's "Arrangement": a psycho-social lens on the contemporary condition of personal life', The Sociological Review. 54:4:846-868.

ROSENEIL, S (2007) Sociability, Sexuality, Self: relationality and individualization London: Routledge.

SIMPSON, R. (2005) "'Living Like the (Bridget) Jones's?' Using the BHPS to research whether there is a delay or decline in partnership formation in Great Britain", Paper presented at the BHPS 2005 Conference, University of Essex, Colchester, 30 June -2 July.

SMART, C. and B. Neale (2003) "Divorce and Marital Separation", Paper presented at CAVA Initial Findings Seminar, University of Leeds, 23 May 2003.

TRIMBERGER, E.Kay (2005) The New Single Woman Boston: Beacon Press.

SAYER, R.A. (1992) Method in Social Science: A Realist Approach London: Routledge.

WASOFF, F. and L. Jamieson with A. Smith (2005) "Solo Living, individual and family boundaries: findings from secondary analysis" in L. McKie and S. Cunningham-Burley (eds) Families in Society: Boundaries and Relationships Bristol: Policy Press.

WINFIELD, F.E. (1985) Commuter Marriages: Living Together, Apart New York: Columbia University Press. 